\title{
E-Waste Management in India
}

\author{
Shilpa S K ${ }^{1}$ \\ Assistant Professor, Electrical \& Electronics Engineering, \\ Bapuji Institute of Engineering and Technology, Davangere, Karnataka ${ }^{1}$
}

\begin{abstract}
Electronic waste or e-waste describes discarded electrical or electronic devices. The composition of e-waste may be electronic components of computer, cell phones, battery, metals and plastic used in cables and in circuit boards. Etc. Electronic gadgets contain thousands of components made of deadly chemicals and metals like lead, cadmium, chromium, mercury, polyvinyl chlorides (PVC). These substances can damage the nervous systems, kidney, bones, reproductive and endocrine systems. The inhalation of toxic fumes, as well as from accumulation of chemicals in soil, water and food. Atmospheric pollution due to burning and dismantling activities seems to be the main cause of occupational and secondary exposure. It effects the environment-to food-chain contamination, as contaminants may accumulate in agricultural lands. The most chemicals of concern have a slow metabolic rate in animals, and may bio accumulate in tissues and be excreted in edible products such as eggs and milk. This paper includes some study of sources of e-waste and its impact on environment. Some of disposal techniques and steps taken by Govt. of India to manage \& utilize the e-waste have been discussed.
\end{abstract}

Keywords: Electronic gadgets, food-chain, e-waste, utilization.

\section{INTRODUCTION}

Electronic waste or e-waste describes discarded electrical or electronic devices. Used electronics which are destined for refurbishment, reuse, resale, salvage recycling through material recovery or disposal are also considered e-waste. The Composition of e-waste may be divided broadly into six categories such as Iron and steel, used for casings and frames, non-ferrous metals especially copper used in cables and aluminium, glass used for screens \& windows, plastic used as casing in cables and for circuit boards, Electronic components and others such as rubber, wood, ceramic etc. The various components of computers such as mother board, SMPS (Switch Mode Power Supply), RAM (Random Access Memory), Hard Disk, Processors, Capacitors, IC se (Integrated Circuits), Main Board, Magnetic Touching Sheet, CD Drive, Floppy Drive and Diodes etc and the various parts of televisions such as Capacitors, Resistors, Transformers, STR (Supply Transformer Regulator), Integrated Circuits (ICs), LOT (Line output Transformer), Tuners, Condensers, CPT Socket (Colour Picture Tube), Zener Diode and Normal Diode etc. and the parts of mobile phone such as Lens, internal antenna, aerial, speakers, earpiece, microphone, microphone connectors, loud speakers, buzzers, ringers, charging blocks, system connectors, chassis, slide mechanism, ribbon cables, sim slot covers, readers, backup, battery, battery clip, covers, battery contacts, connectors and key pad membrane all comes under e-waste.

It is estimated that nearly 50 million tons of E-waste are produced each year. The USA discards 30 million computers each year and 100 million phones are disposed of in Europe each year. The Environmental Protection Agency estimates that only $15-20 \%$ of e-waste is recycled, the rest of these electronics go directly into landfills and incinerators. A record 53.6 million Metric tonnes (Mt) of electronic waste was generated worldwide in 2019, up 21 per cent in just five years, according to the UN's Global E-waste Monitor 2020. The new report also predicts global e-waste - discarded products with a battery or plug - will reach $74 \mathrm{Mt}$ by 2030, almost a doubling of e-waste in just 16 years. This makes e-waste the world's fastest-growing domestic waste stream, fuelled mainly by higher consumption rates of electric and electronic equipment, short life cycles, and few options for repair. Only 17.4 per cent of 2019's e-waste was collected and recycled. Iron, aluminium, and copper represent the majority of the total weight of raw waste materials that can be found in e-waste in 2019. The demand of iron, aluminium, and copper for the production of new electronics in 2019 was approximately $39 \mathrm{Mt}$. Even in an ideal scenario in which all the iron, copper and aluminium resulting from e-waste (25 Mt) is recycled, the world would still require approximately $14 \mathrm{Mt}$ of iron, aluminium and copper from primary resources to manufacture new electronics [3].

India is the "fifth largest electronic waste producer in the world"; approximately 2 million tons of e-wastes are generated annually and an undisclosed amount of e-waste is imported from other countries around the world [4]

Annually, computer devices account for nearly $70 \%$ of e-waste, $12 \%$ comes from the telecom sector, $8 \%$ from medical equipment and $7 \%$ from electric equipment. The government, public sector companies, and private sector companies generate nearly $75 \%$ of electronic waste, with the contribution of individual household being only $16 \%$ [5]. 
It is estimated that throughout India, 400,000-500,000 child workers between the ages of 10-15 are involved in e-waste recycling activities [6]. Hazardous chemical absorption can have a negative effect on a child's growth and can cause permanent damages. Children are particularly sensitive to lead poisoning; it is found that the e-waste recycling activities had contributed to the elevated blood lead levels in children [7]. In Delhi alone, an estimated 25,000 workers including children are involved in crude e-waste dismantling units - annually these units dismantle 10,000-20,000 tons of e-waste with bare hands [8]

Approximately 500 litres of industrial waste, which includes e-waste, are dumped into the Ganges and Yamuna river daily, which has led to the formation of toxic foam. Soil sample analysis conducted by the SRM Institute of Science and Technology found the average concentration Polychlorinated biphenyls (PCBs) in Indian soil to be two times higher than the average amount globally. In India, PCB compounds are most prevalent in urban areas with the highest rate of soilcontamination found in Chennai (a city that imports e-waste), followed by Bengaluru, Delhi and Mumbai.

In recent years, the media and environmental groups have regularly exposed the smuggling and dumping of e-waste. The illegal trade is primarily driven by profit, with a multimillion-dollar turnover, and the globalization of the illegal e-waste trade has intensified corporate, or "white-collar", crime. The lack of reliable data on illegal waste activity is recognized to be a problem as the most common methods of illegal export.

\section{NEED OF E-WASTE MANAGEMENT}

E-waste is much more hazardous than many other municipal wastes because electronic gadgets contain thousands of components made of deadly chemicals and metals like lead, cadmium, chromium, mercury, polyvinyl chlorides (PVC), brominated flame retardants, beryllium, antimony and phthalates. Long-term exposure to these substances damages the nervous systems, kidney, bones, reproductive and endocrine systems. Some of them are carcinogenic and neurotoxic. The E-waste contains both hazardous and non-hazardous substances in their components. These hazardous substances like plastic, lead, mercury, cadmium, arsenic etc. pose health hazards on the human being to the most when treated in uncontrolled condition via air, water and soil.

Table 1. Shows some of the Pollutants in e-waste

\begin{tabular}{|l|l|l|}
\hline SI No & \multicolumn{1}{|c|}{ Pollutant } & \multicolumn{1}{c|}{ Occurrence } \\
\hline $\mathbf{1 .}$ & Lead & $\begin{array}{l}\text { Lead rechargeable batteries, solar, transistors, lithium batteries, PVC (polyvinyl } \\
\text { chloride) stabilizers, lasers, LEDs, thermoelectric elements, circuit boards }\end{array}$ \\
\hline $\mathbf{2 .}$ & Cadmium & $\begin{array}{l}\text { Batteries, pigments, solder, alloys, circuit boards, computer batteries, monitor } \\
\text { cathode ray tubes (CRTs) }\end{array}$ \\
\hline $\mathbf{3 .}$ & Mercury & $\begin{array}{l}\text { Components in copper machines and steam irons; batteries in clocks and pocket } \\
\text { calculators, switches, LCDs }\end{array}$ \\
\hline 4. & Lithium & Mobile telephones, photographic equipment, video equipment (batteries) \\
\hline $\mathbf{5 .}$ & Arsenic & Semiconductors, diodes, microwaves, LEDs (Light-emitting diodes), solar cells \\
\hline $\mathbf{6 .}$ & $\begin{array}{l}\text { PCBs (polychlorinated } \\
\text { biphenyls) }\end{array}$ & Transformers, capacitors, softening agents for paint, glue, plastic \\
\hline 7. & Selenium & Photoelectric cells, pigments, photocopiers, fax machines \\
\hline $\mathbf{8 .}$ & Silver & Capacitors, switches (contacts), batteries, resistors \\
\hline 9. & Zinc & Steel, brass, alloys, disposable \\
\hline
\end{tabular}

\section{E-WASTE DISPOSAL METHODS}

1. Land filling: This is the most common methodology of e-waste disposal. Soil is excavated and trenches are made for burying the e-waste in it. An impervious liner is made of clay or plastic with a leachate basin for collection and transferring the e-waste to the treatment plant. However, landfill is not an environmentally sound process for disposing off the e-waste as toxic substances like cadmium, lead and mercury are released inside the soil and ground water.

2. Acid Bath: Acid bath involves soaking of the electronic circuits in the powerful sulphuric, hydrochloric or nitric acid solutions that free the metals from the electronic pathways. The recovered metal is used in the manufacturing of other products while the hazardous acid waste finds its ways in the local water sources.

3. Incineration: This is a controlled way of disposing off the e-waste and it involves combustion of electronic waste at high temperature in specially designed incinerators. This e-waste disposal method is quite advantageous as the 


\section{DOI 10.17148/IJIREEICE.2020.8801}

waste volume is reduced extremely much and the energy obtained is also utilized separately. However, it is also not free from disadvantages with the emission of the harmful gases mercury and cadmium in the environment.

4. Recycling of e-waste: Mobile phones, monitors, CPUs, floppy drives, laptops, keyboards, cables and connecting wires can be re-utilized with the help of the recycling process. It involves dismantling of the electronic device, separation of the parts having hazardous substances like CRT, printed circuit boards etc. and then recovery of the precious metals like copper, gold or lead can be done with the help of the efficient a powerful e-waste recycler. The most crucial thing here is choosing the right kind of recycler that does not break laws and handle the e-waste in the eco-friendly manner.

5. Reuse of electronic devices: This is the most desirable e-waste recycling process where with slight modifications the mobile phones, computers, laptops, printers can be reused or given as second hand product to the other person. The old electronic equipment can also be donated in the various charity programs and thus helping the persons in need. Moreover, there is a better way also by selling the old mobile phones or laptops to some recycling and refurbishing companies. Several websites are acting as the middleman between recyclers and electronic users. It is a win-win situation for the users as they not only get rid of the old mobile phones but also get paid after reselling it.

6. Protective protocol for workers in e-waste disposal: Workers are given formally recognized jobs where they can use skills and where occupational health safety i.e., information about their occupation-related health hazards involved and self-protection, protective gear and equipment and periodic medical check-ups are assured.

\section{E-WASTE MANAGEMENT IN INDIA}

About 95 per cent of India's e-waste is recycled in the informal sector and in a crude manner. A report on e-waste presented by the United Nations (UN) in World Economic Forum on January 24, 2019, points out that the waste stream reached 48.5 MT in 2018 and the figure is expected to double if nothing changes. Only 20 per cent of global e-waste is recycled. The UN report indicates that due to poor extraction techniques, the total recovery rate of cobalt (the metal which is in great demand for laptop, smart phone and electric car batteries) from e-waste is only 30 per cent. The current e-waste disposal techniques in India have operated mostly in an informal manner due to the lack of enforcement laws and regulations. This has created a new area of economic gain for the country, especially among the urban and rural poor. Though it helps many make a living, those that are disposing of e-waste are usually not aware of the risks and health hazards that result from certain disposal techniques. There are two sectors that handle e-waste disposal and they can be divided into Informal or Formal Sectors [9].

a) Formal sector:The formal sector includes two facilities authorized to deconstruct electronics for the entire country of India and are at capacity with five tons being disposed each day. These facilities primarily receive electronic waste from the producers of "service centers or take-back schemes" or companies that follow the environmental policies on disposing electronic waste. These facilities, though reaching capacity daily, are not the mainstream method of disposal. The formal sector only follows procedure of dismantling and segregating parts. They do not physically dispose of the electronic waste. The informal sector has made it difficult to compete.

b) Informal sector: The informal sector handles electronic waste by recycling or final disposal. Much of electronics that reach India are out of date to more developed countries. Then, within India, these electronics are passed around until no longer of use. There is a whole economic market for electronic waste because the parts can be dismantled and the scrap metals can be recycled. There are recycling techniques that are not following any type of environmental or health standards. Some of the methods used are acid baths, burning cables, and disposing in nature which can be detrimental to the health of those participating in these disposal techniques.

\section{E-WASTE MANAGEMENT REGULATIONS INTRODUCED IN INDIA}

In addition to the Environmental Protection Act of 1986, the E-Waste (Management and Handling) Rules of 2011 came into effect in May 2012. The rules stated that all manufacturers and importers of electronic goods were required to come up with a plan to manage their electronic waste. Producers or importers had to establish e-waste collection centers or employ take back systems. These rules also mandated that sellers of electronic goods must provide consumers with information on how to properly dispose of the electronics in order to prevent people from dumping their electronics with domestic waste. Further, companies that produce electronics which have the potential to become e-waste must make the consumer aware of the hazardous materials in their product. These rules established and placed specific responsibilities for each party involved in the production, disposal, and management of electronic waste. Specific responsibilities were given to the producer, collection centers, consumer or bulk consumer, dismantlers, and recyclers. These rules also 
International Journal of Innovative Research in

Electrical, Electronics, Instrumentation and Control Engineering

Vol. 8, Issue 8, August 2020

\section{DOI 10.17148/IJIREEICE.2020.8801}

mandated that commercial consumers and government departments must keep records of their electronic waste and make them available to state and federal Pollution Control Boards [10]

In October 2016, the E-Waste (Management) Rules, 2016 replaced the E-Waste (Management and Handling) Rules, 2016. This set of rules clarifies duties of responsible parties, enacts more stringent regulations on e-waste production, as well as clarifies the general definition of e-waste. In these rules, e-waste is defined as "electrical and electronic equipment, whole or in part discarded as waste by the consumer or bulk consumer as well as rejects from manufacturing, refurbishment and repair processes. 'Electrical and electronic equipment' in turn has been defined to mean equipment which are dependent on electric current or electro-magnetic field in order to become functional.[11] A major concept presented in these rules is the idea of Extended Producer Responsibility (EPR). Producers of electronic products must implement EPR in order to ensure that their electronic waste is delivered to authorized recyclers or dismantlers. These rules establish and place specific responsibilities for each party involved in the production, disposal, and management of electronic waste. Specific responsibilities were given to the manufacturer, producer, collection centers, dealers, refurbisher, consumer or bulk consumer, recycler, and the state government. These rules also stated target goals for certain industries to drastically reduce their collection of electronic waste.

\section{A) Amendment to the E-Waste Management Rules, 2018}

This amendment relaxes certain aspects of the strict E- Waste (Management Rules of 2016). Specifically, the amendment focuses on the e-waste collection targets by 10\% during 2017-2018, 20\% during 2018-2019, 30\% during 2019-2020, and so on. This amendment also gives the Central Pollution Control Board power to randomly select electronic equipment on the market to test for compliance of rules. The financial cost associated with this testing shall be the responsibility of the government, whereas previously, this responsibility was of the producer [12].

\section{B) Development of waste recycling technologies.}

The Ministry of Electronics and Information Technology (MeitY) has initiated an e-waste awareness programme under Digital India, along with industry associations from 2015, to create awareness among the public about the hazards of ewaste recycling by the unorganized sector, and to educate them about alternate methods of disposing their e-waste. The programme has adopted the best practices for e-waste recycling available globally, so that this sector could generate jobs as well as viable business prospects for locals. The MeitY has developed affordable technologies to recycle valuable materials and plastics in an environmentally sound manner, including two exclusive PCB recycling technologies, through $1000 \mathrm{~kg}$ / day capacity ( 35 MT e-waste) and 100kg/batch $(\sim 3.5 \mathrm{MT}$ e-waste) processes, with acceptable environmental norms.

The $1000 \mathrm{~kg}$ PCB/day continuous process plant would be suitable for creating an eco-park in the country, whereas, the $100 \mathrm{~kg} \mathrm{PCB} / \mathrm{batch}$ process plant would be suitable for the informal sector. This could be done by upgrading and transforming the present state of affairs of informal sectors. E-waste also contains plastic, up to nearly 25 per cent of its weight. Novel recovery and conversion of e-waste plastics to value-added products have also been successfully developed. Professor Veena Sahajwalla, an expert, based in Australia, suggests setting up micro-factories in India that can transform e-waste into reusable material to be converted into ceramics and plastic filaments for 3D printing [13].

\section{SOME OF THE WASTE MANAGEMENT COMPANIES IN INDIA}

Table 2. List of Indian waste management companies \& its description.

\begin{tabular}{|l|l|l|}
\hline Sl.No & Company Name & \multicolumn{1}{c|}{ Company Description } \\
\hline 1 & $\begin{array}{l}\text { Adatte e waste } \\
\text { management }\end{array}$ & $\begin{array}{l}\text { A comprehensive e-Waste management organization that processes the entire } \\
\text { hazardous printed circuit boards waste within and for India in an eco-friendly way }\end{array}$ \\
\hline 2 & Attero & $\begin{array}{l}\text { India's only end-to-end e-Waste recycler and metal extraction company that has also } \\
\text { developed a disruptive technology that sets-up low cost, low capacity ecofriendly } \\
\text { recycling recycling plants for processing e-Waste }\end{array}$ \\
\hline 3 & $\begin{array}{l}\text { BaoBab Clean } \\
\text { Tech }\end{array}$ & $\begin{array}{l}\text { An e-Waste management venture providing solutions that maximize the value recovery } \\
\text { for clients while providing environmentally responsible processes along with managing } \\
\text { liability of the IT assets }\end{array}$ \\
\hline 5 & $\begin{array}{l}\text { Cerebra Integrated } \\
\text { Technologies }\end{array}$ & $\begin{array}{l}\text { Boasting of having one of the largest e-Waste facilities in India, the company offers } \\
\text { repair, refurbishment and reuse of all electronic and electrical equipment's }\end{array}$ \\
\hline 5 & $\begin{array}{l}\text { Uses the best available environmentally sound technologies to mitigate the hazardous } \\
\text { effects of improper treatment and disposal of E-waste, ensuring protection and } \\
\text { preservation of the environment }\end{array}$ \\
\hline
\end{tabular}


International Journal of Innovative Research in

Electrical, Electronics, Instrumentation and Control Engineering

Vol. 8, Issue 8, August 2020

DOI $10.17148 /$ IJIREEICE.2020.8801

\begin{tabular}{|c|c|c|}
\hline 6 & $\begin{array}{l}\text { Ecobirdd } \\
\text { Recycling }\end{array}$ & $\begin{array}{l}\text { Promotes e-waste awareness among businesses and general public and conserves the } \\
\text { nature with its tech-based e-waste recycling solutions }\end{array}$ \\
\hline 7 & EcoReco & $\begin{array}{l}\text { Best-in-class scientific e-waste recycling facility in India that uses latest technologies } \\
\text { from Europe, U.S., and Japan }\end{array}$ \\
\hline 8 & ECS Environment & $\begin{array}{l}\text { Delivers intelligent, improved and personalized solutions which cover the entire life } \\
\text { cycle of IT products through its IT solution centers, remote managed services and e- } \\
\text { waste management }\end{array}$ \\
\hline 9 & Exigo Recycling & $\begin{array}{l}\text { Building a continuum between collection and disposal process of the e-Waste through } \\
\text { its unique EPR (Green Underwriting Services) and rigorous data security solutions } \\
\text { (mobile/portable shredding, witness and prototype destruction services) }\end{array}$ \\
\hline 10 & ExtraCarbon & $\begin{array}{l}\text { Collects recyclable waste from homes \& other commercial places andsends the material } \\
\text { to respective recyclers }\end{array}$ \\
\hline 11 & Green Recycling & $\begin{array}{l}\text { Provides eco-friendly, innovative and economic electronic waste recycling solutions to } \\
\text { the organizations across }\end{array}$ \\
\hline 12 & Greer & $\begin{array}{l}\text { An e-Waste company that collects e-Waste items to reduce, reuse, recycle and recover } \\
\text { them into products through continuous implementation and innovations in recycling } \\
\text { technology }\end{array}$ \\
\hline 13 & GS International & $\begin{array}{l}\text { Provides quality e-Waste recycling programs to assist organizations in treating their e- } \\
\text { waste in a safe manner }\end{array}$ \\
\hline 14 & $\begin{array}{l}\text { High Tech } \\
\text { Recycling }\end{array}$ & $\begin{array}{l}\text { Conducts a responsible in-house de-manufacturing service for non-reusable and/or non- } \\
\text { resalable products in order to achieve the environmental obligations of zero landfill }\end{array}$ \\
\hline 15 & Hulladek & $\begin{array}{l}\text { Offers comprehensive E-Waste Management and handling services on a PAN India } \\
\text { basis }\end{array}$ \\
\hline 16 & $\begin{array}{l}\text { Namo E Waste } \\
\text { Management }\end{array}$ & $\begin{array}{l}\text { A pioneer in asset management and electronics recycling services to efficiently } \\
\text { manage, dispose and recycle discarded electronic items }\end{array}$ \\
\hline 17 & Pruthvi E Recycle & $\begin{array}{l}\text { Engages in recycling the Electronic-Waste CPU, Monitor, Keyboard, Mouse, UPS, and } \\
\text { Power Chords in an organized manner using necessary technology \& methodology }\end{array}$ \\
\hline 18 & Re Teck & $\begin{array}{l}\text { A reverse supply chain management company offering post-consumer take-back and } \\
\text { recycling, closed loop of components and 3R solutions to major electronics \& } \\
\text { technology brands, thereby decreasing e-Waste for used and outdated devices }\end{array}$ \\
\hline 19 & ViroGreen & $\begin{array}{l}\text { Offering a suite of services in e-waste management, including waste management in the } \\
\text { field of electronic and electrical goods, plastics plus data security services }\end{array}$ \\
\hline 20 & $\begin{array}{l}\text { Z Enviro } \\
\text { Industries }\end{array}$ & $\begin{array}{l}\text { Being one of the oldest certified collector and dismantler, it places lot of emphasis on } \\
\text { protecting the environment and encourages people to dispose their e-Waste through } \\
\text { proper channel }\end{array}$ \\
\hline
\end{tabular}

VII. ROLE OF CITIZEN

As responsible citizen, it is our duty to contribute to environment by adopting following simple.

1. Sell Off our outdated Technology: One man's junk is another man's treasure as the old saying goes. This can be applied to helping us to get rid of our old electronics.

2. Donating our outdated Technology: Old gadgets that we no longer need can be donated as they may be useful to others. Our old computer may be useful to either an NGO or students.

3.Visit Civic Institutions: Enquire amongst our government, universities, and schools for any recycling programs they run as a lot of organizations have started assigning a certain day and place for environmentally conscious citizens to come and drop off their e-waste.

4.Give Back to our Electronic Companies and Drop Off Points: A lot of electronic companies tend to have an exchange policy whereby they take back our old gadgets when we buy a later version, sometimes offering us a discount on our new purchase. A few recycling companies have set up electronic drop off initiatives along with drop off points for products such as cell phones and tablets after which they are recycled.

Precautions to Take Before Donating or Recycling our Electronics:

$>$ Upgrade our computer instead of simply replacing it.

$>$ Format all our personal information from our products before discarding. 
International Journal of Innovative Research in

Electrical, Electronics, Instrumentation and Control Engineering

Vol. 8, Issue 8, August 2020

\section{DOI 10.17148/IJIREEICE.2020.8801}

Take out the batteries from our gadgets before getting rid of them.

\section{CONCLUSION}

It is not possible to live without technology now a days but can be minimized. Encouraging entrepreneurs to use various components of e-waste to manufacture a new product and government should give special subsidy to such manufacturing units. Health Hazards for all life forms available on planet earth supporting proper health of our environment, which is ultimate goal on the planet earth. India now has 178 registered e-waste recyclers, accredited by the state governments to process e-waste. But many of India's e-waste recyclers aren't recycling waste at all. While some are storing it in hazardous conditions, others don't even have the capacity to handle such waste, as per by the report of Union Environment ministry .Since India is highly deficient in precious mineral resources (whereas untreated e-waste goes to landfill), there is need for a well-designed, robust and regulated e-waste recovery regime which would generate jobs as well as wealth.

\section{REFERENCES}

[1]. "The global impact of e-waste Addressing the challenge", International Labour office, Geneva.

[2]. Impact of Electronic Waste Leading To Environmental Pollution Y.Sitaramaiah1, M.Kusuma Kumari.

[3]. The Global E-waste Monitor 2020,Journal, Vanessa Forti, Cornelis Peter Baldé, Ruediger Kuehr, Garam Bel ISBN Digital: 978-92-808-9114-0.

[4]. "India fifth largest producer of e-waste: study - The Hindu". The Hindu. 15 May 2016. Archived from the original on 28 November 2016.

[5]. Park, Miles. "Electronic waste is recycled in appalling conditions in India". The Conversation. Retrieved 2019-03-27.

[6]. Joon, Veenu; Shahrawat, Renu; Kapahi, Meena (September 2017). "The Emerging Environmental and Public Health Problem of Electronic Waste in India". Journal of Health and Pollution. 7 (15): 1-7. doi:10.5696/2156-9614-7.15.1. ISSN 2156-9614. PMC 6236536. PMID 30524825.

[7]. Brigden, K "Recycling of electronic wastes in China \& India: workplace \& environmental contamination". Greenpeace. Retrieved 28 Mar 2019.

[8]. Monika, Jugal. "E-waste management: As a challenge to public health in India". Indian Jour of Community Medicine. Retrieved 28 Mar 2019.

[9]. Borthakur, A., \& Sinha, K.Borthakur, A., \& Sinha, K "Electronic Waste Management in India: A Stakeholder's Perspective". Electronic Green Journal.

[10]. E-waste (Management and Handling) Rules, 2011 http://www.ecoraksha.com

[11]. "E-waste Management Rules, 2016

[12]. E-Waste Management Rules Amended https://blog.scconline.com/post/2018/03/27/e-waste-management-amendment-rules-2018-notified/

[13]. Borthakur,A., \& Sinha, K.Borthakur, A., \& Sinha, K. "Electronic Waste Management in India: A Stakeholder's Perspective". Electronic Green Journal. 